Review

\title{
Global distribution of two polystyrene-derived contaminants in the marine environment: A review
}

\author{
Gabriel Enrique De-la-Torre ${ }^{a, *}$, Diana Carolina Dioses-Salinas ${ }^{\mathrm{a}}$, Carlos Ivan Pizarro-Ortega ${ }^{\mathrm{a}}$, \\ Miguel Saldaña-Serrano ${ }^{\mathrm{a}, \mathrm{b}}$ \\ ${ }^{a}$ Universidad San Ignacio de Loyola, Av. La Fontana 501, Lima 12, Peru \\ ${ }^{\mathrm{b}}$ Laboratory of Biomarkers of Aquatic Contamination and Immunochemistry, Department of Biochemistry, Federal University of Santa Catarina, UFSC, Florianópolis, SC, \\ Brazil
}

\section{A R T I C L E I N F O}

\section{Keywords:}

Hexabromocyclododecane

Styrene oligomers

Plastic pollution

Flame retardant

Toxicity

Additive

\begin{abstract}
A B S T R A C T
Plastic pollution is one of the major issues impacting on the marine environment. Plastic polymers are known to leach industrial chemicals and associated contaminants. In this review, we focused on assessing the global distribution and concentration of two polystyrene-derived contaminants, hexabromocyclododecanes (HBCDs) and styrene oligomers (SOs), in marine sediments and seawater. Overall, most of the studies were carried out in Asia, North America, and Europe. Relatively high concentrations of these contaminants are generally attributed to the proximity of urban cities, plastic industries, polystyrene pollution, and aquaculture. Moreover, the concentrations in sediments are many times higher than in seawater. HBCDs were found to be a negligible risk to marine biota when compared to the ecotoxicological endpoints. However, realistic concentrations of SOs could compromise the wellbeing of certain species in highly polluted sites. The future perspectives and research were discussed.
\end{abstract}

\section{Introduction}

Plastic, which was once a revolutionary material, has gradually become a global environmental threat (Frias and Nash, 2019). Global plastic production increases every year as it has become part of almost every aspect of our life (Ma et al., 2020; PlasticsEurope, 2019), from food packaging to medical and technological applications (Frias and Nash, 2019). Only in 2018, world plastic production almost reached 360 million tons (PlasticsEurope, 2019). Polystyrene (PS) is a widely used polymer type of plastic, being the 6th most demanded plastic in Europe in 2018 and having a similar position on the global demand of plastic in 2015 (PlasticsEurope, 2019; Ryberg et al., 2018). PS is an amorphous thermoplastic made from styrene monomer, which exhibits low specific weight, high transparency and brilliance, absence of color, low shrinkage, chemical inertness, and a simple production process (Begum et al., 2019; Gausepohl and Nießner, 2001). It can be found in the market under different varieties, such as general-purpose polystyrene (GPPS), high impact polystyrene (HIPS), expanded polystyrene (EPS), and extruded polystyrene (XPS). Because of its characteristics, PS has been widely used as a packaging material for food and non-food applications, as a building insulator, on the manufacture of household items, on aquaculture, and on the electric, electronic and automobile industries (Begum et al., 2019; Chen et al., 2018; Gausepohl and Nießner, 2001; Gu et al., 2017).

Much of the PS plastic produced end up in the marine environment causing concern about the potential effects on wildlife, ecosystems, and, ultimately, human health (Jambeck et al., 2015; Rochman et al., 2013). Moreover, microplastics, a group of plastic debris smaller than $5 \mathrm{~mm}$, have become widespread and persistent contaminants in the environment (Dioses-Salinas et al., 2020; Kühn et al., 2015). Plastics carry toxic additives that can leach into the marine environment (Capolupo et al., 2020) and compromise the survival of marine species (De-la-Torre, 2020). Antioxidants, UV stabilizers, processing lubes, antistats, and flame retardants (FRs) are some of the additives incorporated to PS (Smith and Taylor, 2002). FRs are used in synthetic polymers to prevent combustion and delay the spread of fire after ignition (Kemmlein et al., 2003). For example, brominated flame retardants (BFR) are one of the most widely used additives (Tongue et al., 2019), which have shown to be persistent pollutants, bioaccumulative and toxic to the environment (Aresta et al., 2003).

Hexabromocyclododecanes (HBCDs) are non-aromatic BFRs used globally mainly in the production of EPS and XPS foams insulations and as an additive for textile coating (Covaci et al., 2006; UNEP, 2015). HBCDs are also used on a minor scale as additives for HIPS, packaging

\footnotetext{
* Corresponding author at: Universidad San Ignacio de Loyola, Faculty of Engineering, Av. la Fontana 501, La Molina, Lima, Peru.

E-mail address: gabriel.delatorre@usil.pe (G.E. De-la-Torre).
} 
materials, paints, and adhesives (UNEP, 2015; US EPA, 2018). HBCDs are widespread, being reported on air, water, sediment, soil, and biota; even in remote areas such as Antarctica, Greenland, Svalbard, and other Arctic regions (Cao et al., 2018; Chen et al., 2015; Covaci et al., 2006; de Wit et al., 2010; Law et al., 2014). HBCDs have been included in Annex A of the Stockholm Convention on Persistent Organic Pollutants since May of 2013 (UNEP, 2013). Therefore, parties of the convention must take measures to eliminate the production and use of this chemical. Over 180 nations have ratified this convention, although the United States has not. Nevertheless, the manufacture and importation of HBCDs in the United States have at least significantly decreased due to the availability of other alternative flame retardants (US EPA, 2018). However, many products containing HBCDs that were produced before the ban may still be available on the market.

Apart from plastic additives, synthetic polymer analogues may also leach into the environment. For instance, styrene oligomers (SOs) originate from the degradation of styrene-based polymeric materials (Kwon et al., 2015) such as PS (Amamiya et al., 2019), resins, and rubbers (Kwon and Moon, 2019). SOs encompass styrene monomers (SMs), styrene dimers (SDs), and styrene trimers (STs) (ECHA, 2019). They are persistent pollutants (Kwon and Moon, 2019), and their presence in water, sediment, and soil have been reported in Europe, Asia, Africa, and America (Hong et al., 2016; Kwon et al., 2014, 2015, 2017; Saido et al., 2014; Yoon et al., 2020). Furthermore, they are considered dangerous for aquatic environments and are suspected to be carcinogenic (ECHA, 2019).

Studies carried out mainly in Europe, Asia and North America indicated that the presence of HBCDs and SOs in the environment appears to be on the rise. However, knowledge about their sources, toxicity, and distribution is scattered, making it difficult to understand and assess the risk of PS pollution and identify the possible sources in marine environments. This review will focus on the global distribution and concentration of HBCDs and SOs in the marine sediment and seawater matrices. Literatures were retrieved and the collected data was standardized and analyzed using a geographic information system. Moreover, we reviewed the toxicological effects of these contaminants in different aquatic organisms and compared the toxicological endpoints to the realistic environmental concentrations reported globally. We aim to establish the potential risk that these contaminants pose in the marine environment and determine future research needs.

\section{Literature review strategy and data treatment}

A literature search was carried out in May 2020, to retrieve articles on the occurrence of HBCDs and SOs in marine sediments and seawater. The Scopus (https://www.scopus.com) database was selected for this purpose. The keywords used in the literature search were "Hexabromocyclododecane", "HBCD", "Styrene oligomer" or "SOs" in conjunction with "sand", "seawater", "sediment", "estuary", "marine" and "ocean". The reference list of the selected studies was retrieved as well if deemed necessary. The focus of the present review is regarding marine environments, thus only articles assessing coastal or deep-water sediments, offshore, estuarine, and coastal waters were retrieved.

The concentrations of HBCDs and SOs in sediments reported in the selected studies were normalized to $\mu \mathrm{g} / \mathrm{kg}$ of dried weight (dw), while HBCDs and SOs in seawater were expressed in ng/L and $\mu \mathrm{g} / \mathrm{L}$ respectively. For geospatial visualization and analysis, the data was classified according to their nearest locations (e.g., province, region, or state) based on the sampling sites reported in the literature. Maps and data processing were carried out using ArcGIS 9.3 (Esri Company).

\section{Results}

\subsection{Sediments}

A total of 20 studies reporting concentrations of HBCDs in sediments from marine or estuarine environments were retrieved. The sampling years ranged from 2000 to 2016 and encompassed a total of 13 countries across Asia, Europe, North America, and Oceania (Figs. 1, 2). The first reports of HBCDs were conducted by Klamer et al. (2005) in Dutch coastal zones and the North Sea, concentrations ranging from $<0.20$ to $6.9 \mu \mathrm{g} / \mathrm{kg} \mathrm{dw}$ and an overall mean of $3.39 \mu \mathrm{g} / \mathrm{kg} \mathrm{dw}$. The highest concentration was reported on China, in Bohai Bay (Tianjin city), Hebei Province, with $60.8 \mu \mathrm{g} / \mathrm{kg} \mathrm{dw}$, ranging from 17.4 to $244 \mu \mathrm{g} / \mathrm{kg} \mathrm{dw}$ (Zhang et al., 2013). The lowest concentrations were reported in China as well, in Zhejiang Province, where it ranged from $<0.01$ to $0.16 \mu \mathrm{g} /$ $\mathrm{kg} \mathrm{dw}$ with an average of $0.05 \mu \mathrm{g} / \mathrm{kg} \mathrm{dw}$ and a low detection frequency (37\%) (Zhu et al., 2013). Overall, high variability in the concentration of HBCDs has been observed within the same region. By considering these results, it is apparent that high HBCDs concentration may be representative of site-specific factors, rather than region-scale drivers. Although, low concentrations in sites of no apparent source of HBCDs could be due to diffuse sources of long-range transport (Covaci et al., 2006). Importantly, a sediment core analysis showed that the concentrations of HBCDs along with PBDEs in the sediments of the Sydney estuary have been increasing over time. For instance, the concentration of HBCDs in Iron Cove was $0.056 \mu \mathrm{g} / \mathrm{kg} \mathrm{dw}$ in the $1980 \mathrm{~s}, 0.12 \mu \mathrm{g} / \mathrm{kg} \mathrm{dw}$ in the early $1990 \mathrm{~s}, 0.43 \mu \mathrm{g} / \mathrm{kg} \mathrm{dw}$ in the late $1990 \mathrm{~s}$, and $1.8 \mu \mathrm{g} / \mathrm{kg} \mathrm{dw}$ in 2014 (Drage et al., 2015). The complete dataset of concentrations is shown in Table S1.

The high HBCDs contamination levels in Bohai Bay may be due to a drainage canal discharging water into the bay and ship activities (Zhang et al., 2013). The HBCD concentration (average of $83.7 \mu \mathrm{g} / \mathrm{kg}$ $\mathrm{dw}$ ) in sediments from the drainage canal surpassed that of Bohai Bay. The proximity of a PS material producing plant is likely to be attributed to the high contamination in the drainage canal, leading to marine pollution with BFRs (Zhang et al., 2013). On the other hand, the low to negligible concentrations in marine sediments from the Zhejiang Province was much lower than that of the sediments of the Yangtze River Delta (Zhu et al., 2013). It was found that the concentration of various BFRs decreased towards offshore sampling sites. No direct source of HBCDs was found to be impacting the river delta, but the proximity to highly urbanized areas, where manufacturing plants are present, may be causing a higher concentration of HBCDs in inland water sediments (Zhu et al., 2013). Apart from urban sites and highly populated cities, wastewater discharge contributes to substantial HBCD contamination even in remote locations, such as research stations in Antarctica (Chen et al., 2015). Moreover, the use of PS materials, such as EPS buoys, has been determined as a source of HBCDs in aquaculture farms (Al-Odaini et al., 2015).

Jang et al. (2017) conducted a large-scale detection of HBCDs in stranded EPS materials and microplastics, suggesting that EPS litter are one major source of hazardous chemical release and could potentially travel long distances, working as an HBCDs vector. Few leaching experiments have evaluated the capacity of PS products and debris to release HBCDs and SOs into the marine environment under natural conditions (Aminot et al., 2020; Rani et al., 2017; Tian et al., 2020). PS seems to rapidly release high concentrations of HBCDs, probably due to the rapid desorption of the substance from the surface of the debris (Aminot et al., 2020; Rani et al., 2017). EPS spherules lost $61 \%$ of their HBCD content after 7 days of exposure to open sea surface conditions (Rani et al., 2017). This rapid initial leaching can be followed by a slower release of internal HBCDs over a long period, although this capacity may be affected by the debris characteristics and environmental factors (Aminot et al., 2020). The exposure to sunlight, the temperature, strong biofouling, water flow, the increase of the fragment surface area by fragmentation or water movement are factors that increase the leaching of HBCDs from EPS and probably from other types of PS as well (Rani et al., 2017).

Unlike HBCD, SOs seems to have a lower and slower leaching rate from PS debris. EPS buoys particles lost only $0.031 \% \pm 0.004 \%$ of the total SOs concentration through leaching after 5 days of exposure in 


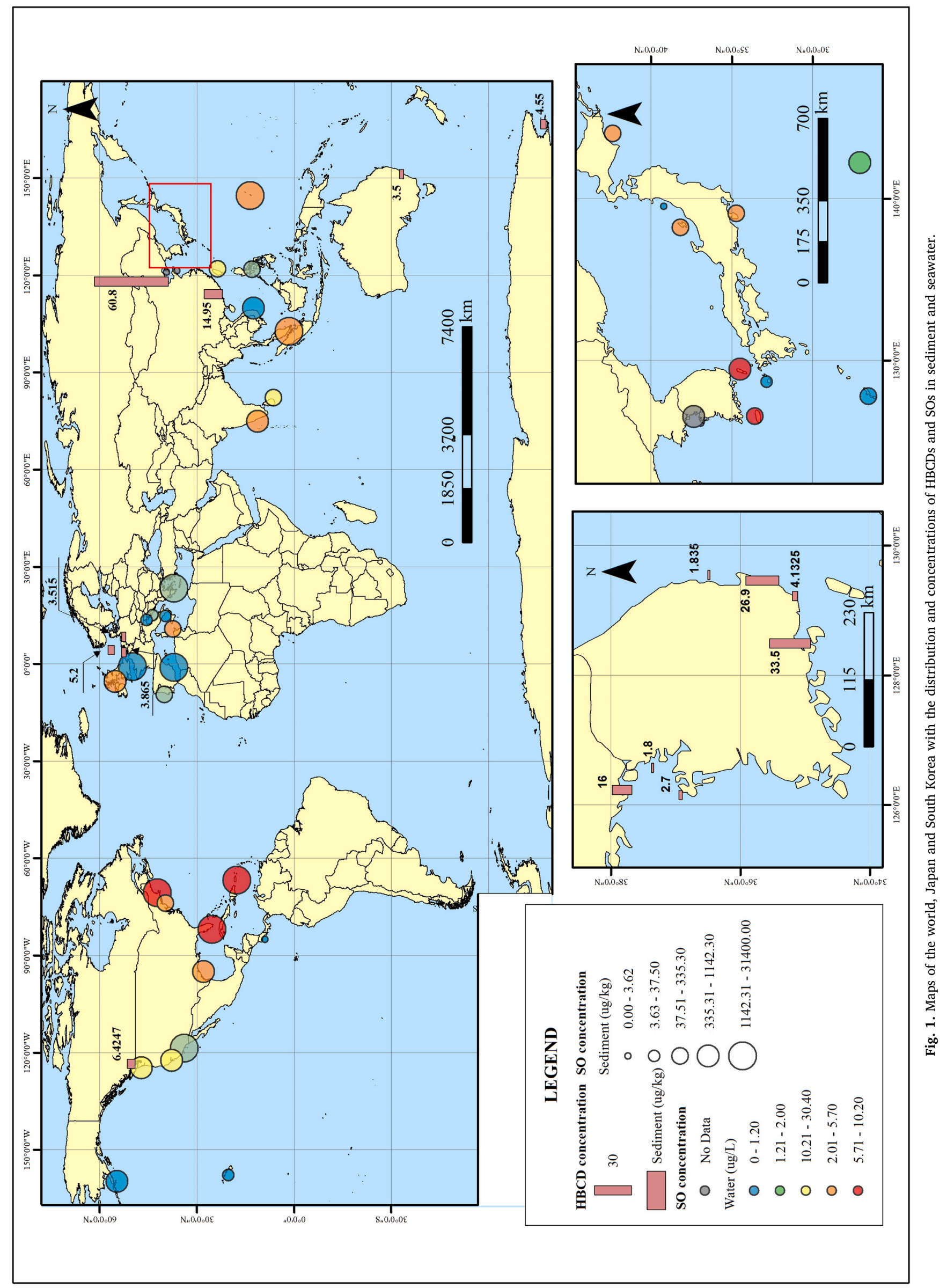


laboratory conditions (Tian et al., 2020). Even though the leached concentration of SOs in this study was small, the results suggest that other PS products and debris may leach SOs into the environment, and thus further studies are needed. Based on this, marine-coastal areas with a high abundance of PS and, particularly, EPS litter or microplastics are especially subject to pollution with polystyrene-associated compounds, including HBCDs and SOs (De-la-Torre et al., 2020). This is further supported by a recent study reporting a positive and significant correlation between BFRs, including HBCDs, and microplastic abundance in estuarine sediments (Zuo et al., 2020). In water streams, high concentrations of HBCDs travel relatively short distances. Zhang et al. (2018) investigated the transport of HBCDs from the discharge point located in a river and many kilometers downstream. It was observed that the initial concentration of HBCDs (5080 ng/L) significantly decreased after $2 \mathrm{~km}$, reaching $75.3 \mathrm{ng} / \mathrm{L}$ and down to $27.9 \mathrm{ng} / \mathrm{L}$ after $4 \mathrm{~km}$. Given that PS debris is an important source of HBCDs and SOs, their buoyancy and widespread use suggest that PS may serve as a vector of associated contaminants in the marine environment. Thus, the transport mechanism relies mainly on the disposal and drift of PS debris across the ocean. For instance, Saido et al. (2014) suggested that washup plastic debris is an important source of SOs in Japan. In this sense, the fate of drifting PS debris, conditioned by surface oceanic currents, is an important driver of HBCDs and SOs.

A total of 7 studies that reported concentrations of SOs in sediments from marine or estuarine environments were retrieved. The sampling years are documented between 2003 and 2018, covering a total of 20 countries from Africa, Asia, Europe, and North America. The first reports on the concentration of these contaminants in both sediment and seawater were made by Kwon et al. (2015) in American, European, African, and Asian countries. In European countries, the highest mean concentrations were reported in Greece with $31,400 \mu \mathrm{g} / \mathrm{kg}$, and France with $4496.6 \mu \mathrm{g} / \mathrm{kg}$. In Asia, the highest concentrations were reported in Malaysia $(18,924.8 \mu \mathrm{g} / \mathrm{kg})$, followed by China $(1408.2 \mu \mathrm{g} / \mathrm{kg})$. Regarding North America, the highest concentration was found in Los Angeles $(29,106.8 \mu \mathrm{g} / \mathrm{kg})$ and Florida $(23,507 \mu \mathrm{g} / \mathrm{kg})$. In Africa, Tunisia registered a concentration of $92 \mu \mathrm{g} / \mathrm{kg}$. Saido et al. (2014) focused on assessing eight Japanese islands, Tokyo, and one Korean Island. Results indicated that the islands of Tsushima $(1142.3 \mu \mathrm{g} / \mathrm{kg})$ and Okinawa $(643.6 \mu \mathrm{g} / \mathrm{kg})$ were the most contaminated. Interestingly, the study by Kwon et al. (2015) reported much lower concentrations in Okinawa, with $69.3 \mu \mathrm{g} / \mathrm{kg}$. This could be due to site-specific SOs sources and sinks or a rather uneven distribution of SOs within a small territory. This is supported by the high variability of SOs concentration in Okinawa as reported by Saido et al. (2014), ranging from 0 to $8000 \mu \mathrm{g} / \mathrm{kg}$ across 34 sampling sites.

By observing the worldwide occurrence of SOs, it is apparent that the SOs have become ubiquitous but highly variable in the marine environment. The high levels of contamination could be due to the number of anthropogenic activities carried out in the sampled sites (Saido et al., 2014), while low concentrations may be attributed to the remoteness of large-scale factories and the human population (Kwon et al., 2015). Although it is argued that the hydrophobicity of SOs prevents it from traveling to remote areas (Hong et al., 2016), Amamiya et al. (2019) found a positive correlation between SOs concentration in sand and precipitation events in Tokyo Bay. This indicates that weather events could drive SOs from land sources to coastal areas. Same as in HBCDs, PS plastic pollution presents a higher risk of SOs pollution. Weathering conditions, such as wind, wave actions, or drag forces, start and accelerate SOs leaching from marine PS debris (Kwon et al., 2015). Washed-up PS debris from oceanic surface currents may also act as a source of PS plastic pollution and SOs leaching (Saido et al., 2014). Upon leaching, SOs adsorb to sand grains and persist in the sediment matrix for an unknown period (Kwon et al., 2015). Hong et al. (2016) reported a much higher concentration of SOs in inland creeks (mean of $395 \mu \mathrm{g} / \mathrm{kg}$ ) than in the inner and outer parts (mean of $33 \mu \mathrm{g} / \mathrm{kg}$ and $25 \mu \mathrm{g} / \mathrm{kg}$ respectively) of Lake Sihwa, Gyeonggi Bay, South Korea. This distribution is attributed to the inland creeks' proximity to several facilities and industrial complexes, although runoffs from these areas may not play an important role in SOs transport (Hong et al., 2016). Based on this evidence, PS plastics serve as a more significant SOs driver than weathering conditions acting on SOs already released to the environment.

\subsection{Sea water}

Few studies have addressed the occurrence of HBCDs in seawater. Due to the hydrophobic character of the HBCDs, it may be more appealing to study their occurrence on solid particles such as sediments, soil, and sewage sludge. Some of the main sources of HBCDs on water identified are industrial effluents from HBCDs and HBCDs retardant materials manufacturers, as well as effluents from other industries that use products containing HBCDs (e.g. textile industry, plastic industry), leaching from products containing HBCDs throughout its usage and disposal (e.g. EPS buoys, EPS liter), atmospheric deposition and municipal wastewaters (Cao et al., 2018; Covaci et al., 2006; Feng et al., 2012; Gu et al., 2017). Moreover, proximity to the source, water circulation, and the content of suspended particulate matter are some factors that may influence the HBCD concentration in seawater ( $\mathrm{Gu}$ et al., 2017; Vorkamp et al., 2014).

Following our literature review strategy, a total of 4 studies reporting the presence of HBCDs in seawater were retrieved. The sampling campaigns were carried out from 2011 to 2016 in Denmark and South Korea. The overall range of concentrations reported on the studies ranged from No Data (ND) to $1.62 \mathrm{ng} / \mathrm{L}$, presenting the maximum concentration values on aquaculture farms in the province of South Gyeongsang, in South Korea. Such high concentration was attributed to the presence of EPS buoys in those areas (Hong et al., 2013). Surprisingly, the lowest concentration range of HBCDs was reported on a similar study whose survey included South Gyeongsang as well (Gu et al., 2017).

The difference in the results between the two studies may be indicative of the greater influence of site-specific factors than regional drives, as mentioned before. Nevertheless, both studies surveyed areas with a high presence of aquaculture farms. Besides, the effect of inland sources such as industrial complexes, wastewater treatment plants, and shipyards may not be significant in comparison to the EPS buoys, as a similar concentration of HBCDs has been reported on aquaculture farms close to those inland sources and in other sites without them (Gu et al., 2017). The depth of the sampling may have been a factor that influenced the results, as EPS buoys influence may decrease with water depth (Hong et al., 2013). Also, the proximity of the sampling locations to aquaculture areas may be related to the higher concentrations (Hong et al., 2013).

Like the sediment data, sampling years among the 8 retrieved studies ranged from 2003 to 2013, encompassing 20 countries from Africa, Asia, Europe, and North America. Kwon et al. (2015) also investigated the presence of SOs in seawater along with sediment samples, but there was no apparent correlation between the SOs concentration in both matrices. The results of Kwon et al. (2015) showed low levels of SOs contamination, ranging from below the limit of detection $(<\mathrm{LOD})$ to $30.4 \mu \mathrm{g} / \mathrm{L}$ and an overall mean of $5.1 \mu \mathrm{g} / \mathrm{L}$. In contrast, Saido et al. (2014) reported mean concentrations ranging from < LOD to $547.4 \mu \mathrm{g} /$ $\mathrm{L}$, the highest belonging to Okinawa island. The concentration from Honshu Island, Japan, was reported to be $4.7 \mu \mathrm{g} / \mathrm{L}$ (Kwon et al., 2015) but a later study reported $1.48 \mu \mathrm{g} / \mathrm{L}$ in the same region (Kwon et al., 2017). Moreover, SOs levels in Okinawa island were $1.2 \mu \mathrm{g} / \mathrm{L}$ according to Kwon et al. (2015), although a much higher concentration was reported by Saido et al. (2014). The long-term sampling campaigns by Kwon et al. (2015) were carried out in a 10-year period (2003-2013). The sampling periods by Kwon et al. (2017) and Saido et al. (2014) fall within this time range. Thus, it is unknown whether SOs concentration is increasing or decreasing over time. 
The concentrations recorded in seawater are in lower levels of magnitude compared to sediment samples. Kwon et al. (2015) propose that SOs leach from the outer layer of PS plastics instantly, while the inner layers upon weathering conditions and cracking. The leaching process may accelerate under a higher surface area due to PS particle disintegration (Cooper and Corcoran, 2010). Although SOs persist in the sediment matrix through adsorption, only a small part dissolves in seawater due to the hydrophobic nature of these compounds (Hong et al., 2016). As a result, low seawater concentrations of SOs can be found despite being in contact with a highly polluted sand matrix. No specific sources have been identified for seawater other than the ones impacting on coastal sediments.

\section{Ecotoxicity}

Exposure of marine organisms to HBCDs and SOs is expected due to the wide distribution of these contaminants. Bioaccumulation of HBCDs in tissues of bivalves (Gu et al., 2017; Son et al., 2015), fish (Son et al., 2015), polar bears (Dietz et al., 2013), and marine bird eggs (Reindl and Falkowska, 2020) is reported in the literature. Table S2 displays a summary of the studies reporting bioaccumulation of HBCDs in marine biota HBCDs may also biomagnify from prey to predator in the aquatic food web, bioaccumulating in several tissues but mainly in perivisceral adipose tissues (Morris et al., 2004; Tang et al., 2015). Bioassays also demonstrated the high bioaccumulation potential of HBCDs in marine copepod Tigriopus japonicus and medaka Oryzias melastigma (Hong et al., 2014; Shi et al., 2017). To the best of our knowledge, reports of SOs bioaccumulating in organisms' tissues from environmental examples and biomagnification potential are lacking.

Several studies have investigated the acute and chronic effects of HBCDs and styrene (SM) in aquatic organisms (Table 1). Dong et al. (2017) conducted chronic and acute toxicity tests with nine freshwater species exposed to HBCDs in different concentration ranges. The toxic endpoints for acute toxicity were 96 h LC50/EC50 and 48 h LC50 for Daphnia magna. D. manga and Macrobrachium nipponense were the most sensitive species, with acute toxicities of 18.5 and $13.0 \mathrm{mg} / \mathrm{L}$, respectively. Other less sensitive organisms, such as Cipangopaludina cathayensis, Chironomus plumosus, and Limnodrilus hoffmeisteri reached the toxicity endpoint at 1100, 729, and $412 \mathrm{mg} / \mathrm{L}$ respectively. The calculated acute and chronic safety thresholds of HBCDS were 2.32 and $0.128 \mathrm{mg} / \mathrm{L}$ (Dong et al., 2017). Other sublethal effects observed in Zebrafish (Danio rerio) were a significantly high percentage of curved body malformations starting at $2.5 \mathrm{mg} / \mathrm{L}$ and increased glutathione-Stransferase (GST) activity at $5 \mathrm{mg} / \mathrm{L}$ (Usenko et al., 2016). In clam Venerupis philippinarum, low concentrations of HBCDs increased the activity of GST and superoxide dismutase (SOD) enzymes and increased glutathione (GSH) content ( $\mathrm{H}$. Zhang et al., 2014; Y. Zhang et al., 2014).

Kuiper et al. (2007) investigated the chronic effects of HBCD on European flounders (Platichthys flesus). The test was performed in 78 days in which the organisms were exposed through food and sediment to HBCD concentrations up to $3000 \mu \mathrm{g} / \mathrm{g}$ lipid and $8000 \mu \mathrm{g} / \mathrm{g}$ of total organic content (TOC), which can be expressed as $2.4 \mathrm{mg} / \mathrm{kg} \mathrm{dw}$ (EU, 2011). They found a limited potential for in vivo endocrine disruption of the reproductive and thyroid hormonal system. Similar results were found on a toxicity test with Hyalella azteca using sediments with $2 \%$ TOC content and 5\% TOC. The test presented 28 days no observed effect concentration (NOEC) of $1000 \mathrm{mg} / \mathrm{kg} \mathrm{dw}$ (the highest dose tested). There were no apparent effects on the survivorship and growth of the organisms, even if the organic content of the sediment varied (Thomas et al., 2003). Similarly, toxicity tests with the freshwater oligochaete Lubricus variegates and Chironomus riparius were performed for 28 days (Oetken et al., 2001). Significant effects on the mortality were seen since nominal concentrations of $50 \mathrm{mg} / \mathrm{kg} \mathrm{dw}$, while in the case of mean biomass and number of large and small worms the significant effect was reached at a nominal concentration of
$500 \mathrm{mg} / \mathrm{kg} \mathrm{dw}$. In the case of Chironomus riparius significant reduction of the production of eggs of the F1 generation was seen at nominal concentrations of $500 \mathrm{mg} / \mathrm{kg} \mathrm{dw}$. The calculated lowest observed effective concentration (LOEC) for Lubricus variegates and Chironomus riparius was $28.7 \mathrm{mg} / \mathrm{kg} \mathrm{dw}$ and $159 \mathrm{mg} / \mathrm{kg}$ dw respectively, while the normalized NOEC for both species were $8.61 \mathrm{mg} / \mathrm{kg} \mathrm{dw}$ and $37.8 \mathrm{mg} /$ $\mathrm{kg} \mathrm{dw}$.

An early toxicity assessment determined the 4-day LC50 of SM in Pimephales promelas $(10 \mathrm{mg} / \mathrm{L})$ and Hyalella azteca $(9.5 \mathrm{mg} / \mathrm{L})$ (Cushman et al., 1997). A further study found that a 7 days continuous exposure of $0.2 \mathrm{mg} / \mathrm{L} \mathrm{SM}$ to mussel Mytilus edulis and fish Symphodus melops disrupts lysosomal membrane stability and leads to DNA damage in blood cells and haemocyte (Mamaca et al., 2005). Importantly, SM at relatively realistic concentrations impacts on the development of mussel Mytilus galloprovincialis at early life stages, including transcriptional effects on the genes involved in shell biogenesis (Wathsala et al., 2018), a crucial process for assuring the survival in their adult stages. To the best of our knowledge, the toxicity of SD and ST have not been assessed before. This is a key gap in the literature since the concentration of ST in seawater has been reported to be many times higher than SM (Kwon et al., 2014).

\section{Discussion}

Overall, there are no studies reporting concentrations of HBCDs or SOs in any environmental compartment from South America. Only a few studies reported the presence of HBCDs in seawater. For instance, mean concentrations as low as $0.40 \mathrm{ng} / \mathrm{L}$ (Gu et al., 2017) and ranging from 0.08 to $1.62 \mathrm{ng} / \mathrm{L}$ in South Korean surface waters (Hong et al., 2013) and from 0.052 to $0.40 \mathrm{ng} / \mathrm{L}$ in Denmark (Vorkamp et al., 2014) imply that the presence of HBCDs in seawater is negligible when compared to the safety thresholds calculated by Dong et al. (2017) and are not sufficient to induce sublethal effects as reported in the literature for several organisms. Low environmental concentrations are mainly attributed to the solubility of HBCDs ranging from 2 to $5 \mu \mathrm{g} / \mathrm{L}$ at $25{ }^{\circ} \mathrm{C}$ due to their hydrophobic nature (Marvin et al., 2011). Owed to their hydrophobic properties, hydrolysis is considered a non-significant degradation pathway for HBCDs (OECD, 2007). After being uptaken by the marine fauna, bio-isomerization occurs. Mukai et al. (2020) reported that the highest concentrations of $\alpha$-HBCD in oysters (Saccostrea mordax), can be attributed to the bio-isomerization of $\gamma$ - HBCD to $\alpha$ HBCD. Likewise, it was observed that HBCD is debrominated to become new metabolites tetrabromocyclododecadiene (TBCDi) and tribromocyclododecatriene (TriBCDie) in the microalgae Spirulina subsalsa (H. Zhang et al., 2014; Y. Zhang et al., 2014). However, owing to their low concentrations in seawater, HBCDs are a minor concern for aquatic life. On the contrary, most studies focused on the presence of HBCD on sediments. In this matrix, mean concentrations varied from $0.0257 \mu \mathrm{g} /$ $\mathrm{kg} \mathrm{dw}$ to $60.8 \mu \mathrm{g} / \mathrm{kg} \mathrm{dw}$, being reported the minimum and maximum value on British Columbia (Canada) and Tianjin city (China), respectively. Nevertheless, none of the mean concentrations reported and none of the maximum values of the ranges reported surpassed the NOEC calculated for Lubricus variegates $(8.61 \mathrm{mg} / \mathrm{kg} \mathrm{dw}$ ), which was the lowest NOEC. Therefore, we suggest that HBCDs may be a minor concern for sediment organisms.

In contrast. SOs could pose a higher risk to marine biota, given that SOs in seawater are in many times larger orders of magnitude than HBCDs, and SM bioassays reach toxicological endpoints at lower concentrations. According to Wathsala et al. (2018), a significant reduction in normal M. galloprovincialis larvae development, including malformation, is induced from $0.1 \mu \mathrm{g} / \mathrm{L}$ (LOEC), and decreasing at higher concentrations. SOs concentrations in seawater around the globe surpass the LOEC value in most countries (Table S1). Moreover, the concentration $(0.2 \mathrm{mg} / \mathrm{L})$ inducing lysosomal membrane stability disruption and DNA damage in $M$. edulis and fish $S$. melops (Mamaca et al., 2005) is surpassed by only Okinawa Island, with a mean concentration 


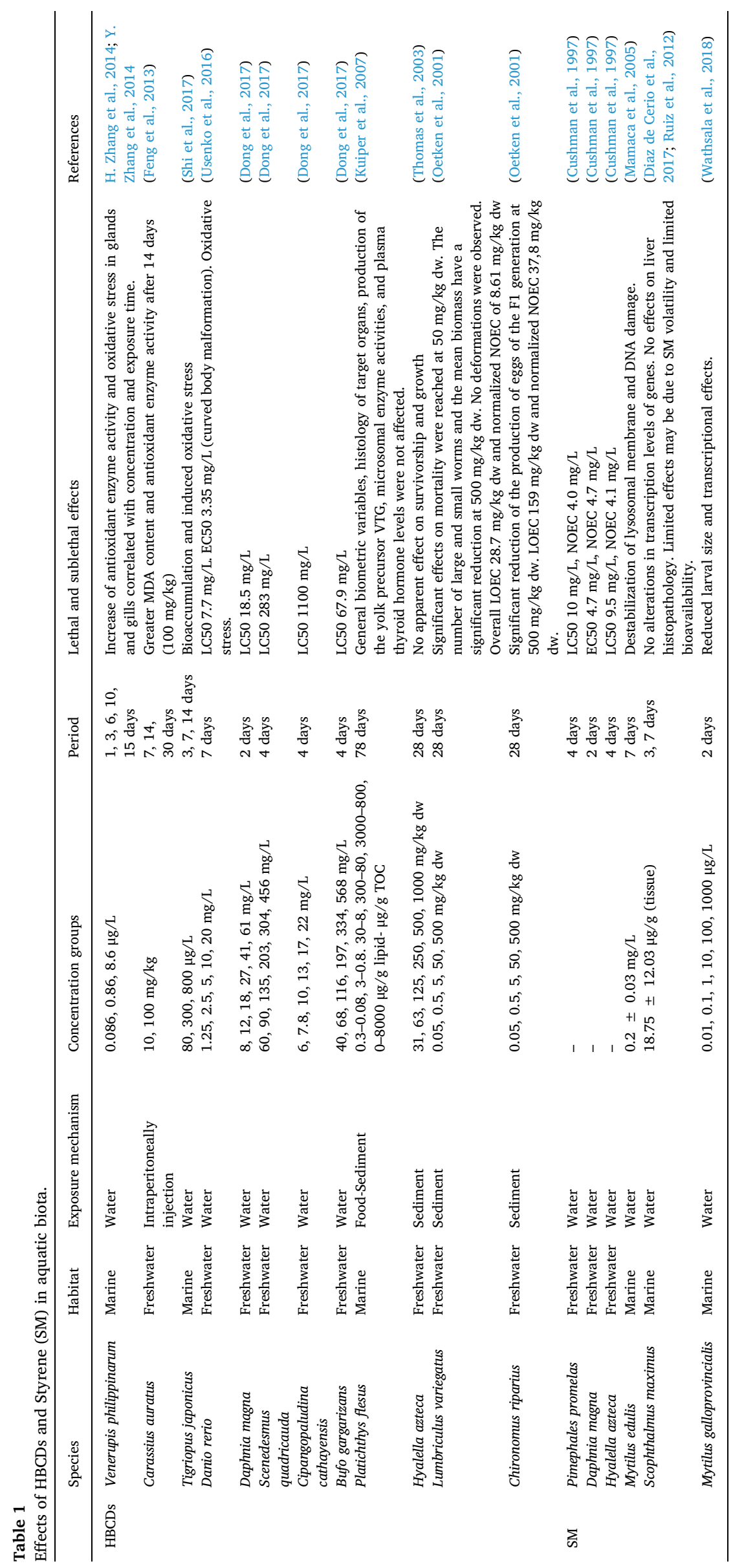


of $547.4 \mu \mathrm{g} / \mathrm{L}$ SM (Saido et al., 2014). There is a high variability of SOs levels among samples within the same location, SM concentrations in Iriomote island (Japan) range from 0 to $517.4 \mu \mathrm{g} / \mathrm{L}$ (mean of $79.2 \mu \mathrm{g} / \mathrm{L}$ ) and in Tokyo range from 0 to $1350 \mu \mathrm{g} / \mathrm{L}$ (mean of 158.6) (Saido et al., 2014). This suggests that toxicological risks may be perceived in sitespecific areas, despite the reduced SO mobility across the environmental matrix. None of the environmental concentrations reported in literature reached lethal endpoints.

Environmental Quality Standards (EQS) and quality guidelines for HBCDs have been developed by the European Union (EU) and Canada. For the case of seawater, the EU has established $0.05 \mu \mathrm{g} / \mathrm{L}$ as the maximum allowable concentration (MAC) (EU, 2013), while the Minister of Environment and Climate Change of Canada (ECCC) determined a quality guideline of $0.56 \mu \mathrm{g} / \mathrm{L}$ in which it is presumed there is a low probability of adverse effect to aquatic life (ECCC, 2016). None of the mean concentrations or concentration ranges reported on the studies surpassed these values. The highest concentration from all the ranges represented $0.4 \%$ of the MAC determined by the EU, which is the lower threshold.

In the EQS dossier for HBCDs, the EU suggested as EQS for marine sediments an annual average of $0.17 \mathrm{mg} / \mathrm{kg} \mathrm{dw}(170 \mu \mathrm{g} / \mathrm{kg} \mathrm{dw})(\mathrm{EU}$, 2011), while the ECCC settled a quality guideline of $1.6 \mathrm{mg} / \mathrm{kg} \mathrm{dw}$ $(1600 \mu \mathrm{g} / \mathrm{kg} \mathrm{dw})$ (ECCC, 2016). None of the mean concentrations reported on the studies surpassed these values. The maximum average value $(60.8 \mu \mathrm{g} / \mathrm{kg} \mathrm{dw})$ reported on Bohai Bay represents $36 \%$ of the EQS of the EU. Nevertheless, concentration ranges reported on Bohai Bay and Southern Hong Kong in China presented maximum values higher than the EQS suggested by the EU (Ruan et al., 2018; Zhang et al., 2013). Besides, the concentration range reported for South Gyeongsang and Jeolla Provinces in South Korea presented a maximum value of just $1.18 \%$ below the threshold (Gu et al., 2017). The authors indicated that a possible reason for such high concentration is the closeness of the sampling site to highly populated areas and boat stopping activities, for Southern Hong Kong and Bohai Bay respectively (Ruan et al., 2018; Zhang et al., 2013). In the case of South Gyeongsang and Jeolla Provinces, EPS buoys for aquaculture activities were identified as the main source of HBCD. It is important to highlight that EU EQS refers to an annual average, so it should just be taken as a reference. No EQS, environmental quality guidelines, or similar regulation were identified for SOs.

\section{Conclusion}

Plastic pollution is a global problem that looks to continue exacerbating over time. Once they reach the environment, plastics leach toxic chemicals, and additives associated with the manufacturing process. Here, the global distribution and concentrations of two significant PSderived contaminants were analyzed, along with the ecotoxicological implications and regulations. High concentrations of HBCDs and SOs may be perceived in specific areas due to site-specific factors, rather than on a regional scale, which may explain the high variability of concentrations found even in small territories such as the Okinawa island or remote territories such as the Antarctic. Nevertheless, the results of various studies suggest a ubiquitous presence of both contaminants in the marine environment. This ubiquitous presence may imply the existence of diffuse sources or long-range transport mechanisms that must be further studied. There is evidence that HBCDs concentration in the marine environment has been increasing over time, but it is unknown whether the SOs concentration is increasing as well. However, the HBCDs concentrations in seawater are negligible compared to safety thresholds and environmental quality standards. Similarly, the maximum average concentration of HBCDs in sediment represents only $36 \%$ of the minimum EQS. This evidence suggests that HBCDs may not pose an important risk to the marine environment. Future ecotoxicological research should conduct chronic assays and evaluate biochemical biomarkers and the potential biomagnification of
HBCDs in different trophic levels. Co-exposure assays with relevant contaminants, such as microplastics, may further elucidate the combined effects of HBCDs with other widespread pollutants.

Overall, the concentrations of HBCDs and SOs in sediment is far higher than in water due to the hydrophobicity of these chemicals. On the other hand, SOs presence in the marine environment is many times higher than HBCDs and toxicological endpoints are reached at lower concentrations. The apparent higher risk along with the lack of international regulation for SO makes it an appealing pollutant to be further studied especially in terms of transport mechanisms, toxicity, biomagnification, and bioaccumulation. As ecotoxicological studies have focused on SMs only, SDs and STs must be assessed to have a complete understanding of the potential risk SOs pose.

\section{Declaration of competing interest}

The authors declare that they have no known competing financial interests or personal relationships that could have appeared to influence the work reported in this paper.

\section{Acknowledgments}

The authors are thankful to Universidad San Ignacio de Loyola for financial support.

\section{Appendix A. Supplementary data}

Supplementary data to this article can be found online at https:// doi.org/10.1016/j.marpolbul.2020.111729.

\section{References}

Al-Odaini, N.A., Shim, W.J., Han, G.M., Jang, M., Hong, S.H., 2015. Enrichment of hexabromocyclododecanes in coastal sediments near aquaculture areas and a wastewater treatment plant in a semi-enclosed bay in South Korea. Sci. Total Environ. 505, 290-298. https://doi.org/10.1016/j.scitotenv.2014.10.019.

Amamiya, K., Saido, K., Chung, S.Y., Hiaki, T., Lee, D.S., Kwon, B.G., 2019. Evidence of transport of styrene oligomers originated from polystyrene plastic to oceans by runoff. Sci. Total Environ. 667, 57-63. https://doi.org/10.1016/j.scitotenv.2019.02. 383.

Aminot, Y., Lanctôt, C., Bednarz, V., Robson, W.J., Taylor, A., Ferrier-Pagès, C., Metian, M., Tolosa, I., 2020. Leaching of flame-retardants from polystyrene debris: bioaccumulation and potential effects on coral. Mar. Pollut. Bull. 151, 110862. https://doi. org/10.1016/j.marpolbul.2019.110862.

Aresta, M., Caramuscio, P., De Stefano, L., Pastore, T., 2003. Solid state dehalogenation of PCBs in contaminated soil using NaBH4. Waste Manag. 23, 315-319. https://doi.org/ 10.1016/S0956-053X(03)00029-1.

Begum, S.A., Rane, A.V., Kanny, K., 2019. Applications of compatibilized polymer blends in automobile industry. In: Compatibilization of Polymer Blends: Micro and Nano Scale Phase Morphologies, Interphase Characterization, and Properties. Elsevier, pp. 563-593. https://doi.org/10.1016/B978-0-12-816006-0.00020-7.

Cao, X., Lu, Y., Zhang, Y., Khan, K., Wang, C., Baninla, Y., 2018. An overview of hexabromocyclododecane (HBCDs) in environmental media with focus on their potential risk and management in China. Environ. Pollut. 236, 283-295. https://doi.org/10. 1016/j.envpol.2018.01.040.

Capolupo, M., Sørensen, L., Jayasena, K.D.R., Booth, A.M., Fabbri, E., 2020. Chemical composition and ecotoxicity of plastic and car tire rubber leachates to aquatic organisms. Water Res. 169, 115270. https://doi.org/10.1016/j.watres.2019.115270.

Chen, D., Hale, R.C., La Guardia, M.J., Luellen, D., Kim, S., Geisz, H.N., 2015. Hexabromocyclododecane flame retardant in Antarctica: research stations as sources. Environ. Pollut. 206, 611-618. https://doi.org/10.1016/j.envpol.2015.08.024.

Chen, X.Y., Romero, A., Paton-Carrero, A., Lavin-Lopez, M.P., Sanchez-Silva, L., Valverde, J.L., Kaliaguine, S., Rodrigue, D., 2018. Functionalized graphene-reinforced foams based on polymer matrices: processing and applications. In: Functionalized Graphene Nanocomposites and Their Derivatives: Synthesis, Processing and Applications. Elsevier, pp. 121-155. https://doi.org/10.1016/B978-0-12-814548-7.00007-6.

Cooper, D.A., Corcoran, P.L., 2010. Effects of mechanical and chemical processes on the degradation of plastic beach debris on the island of Kauai, Hawaii. Mar. Pollut. Bull. 60, 650-654. https://doi.org/10.1016/j.marpolbul.2009.12.026.

Covaci, A., Gerecke, A.C., Law, R.J., Voorspoels, S., Kohler, M., Heeb, N.V., Leslie, H., Allchin, C.R., De Boer, J., 2006. Hexabromocyclododecanes (HBCDs) in the environment and humans: a review. Environ. Sci. Technol. 40, 3679-3688. https://doi. org/10.1021/es0602492.

Cushman, J.R., Rausina, G.A., Cruzan, G., Gilbert, J., Williams, E., Harrass, M.C., Sousa, J.V., Putt, A.E., Garvey, N.A., St. Laurent, J.P., Hoberg, J.R., Machado, M.W., 1997. 
Ecotoxicity hazard assessment of styrene. Ecotoxicol. Environ. Saf. 37, 173-180. https://doi.org/10.1006/eesa.1997.1540.

de Wit, C.A., Herzke, D., Vorkamp, K., 2010. Brominated flame retardants in the Arctic environment - trends and new candidates. Sci. Total Environ. 408, 2885-2918. https://doi.org/10.1016/j.scitotenv.2009.08.037.

De-la-Torre, G.E., 2020. Microplastics: an emerging threat to food security and human health. J. Food Sci. Technol. 57, 1601-1608. https://doi.org/10.1007/s13197-01904138-1.

De-la-Torre, G.E., Dioses-Salinas, D.C., Castro, J.M., Antay, R., Fernández, N.Y., EspinozaMorriberón, D., Saldaña-Serrano, M., 2020. Abundance and distribution of microplastics on sandy beaches of Lima, Peru. Mar. Pollut. Bull. 151, 110877. https://doi. org/10.1016/j.marpolbul.2019.110877.

Diaz de Cerio, O., Bilbao, E., Ruiz, P., Pardo, B.G., Martínez, P., Cajaraville, M.P., Cancio, I., 2017. Hepatic gene transcription profiles in turbot (Scophthalmus maximus) experimentally exposed to heavy fuel oil $\mathrm{n}^{\circ} 6$ and to styrene. Mar. Environ. Res. 123 14-24. https://doi.org/10.1016/j.marenvres.2016.11.005.

Dietz, R., Rigét, F.F., Sonne, C., Born, E.W., Bechshøft, T., McKinney, M.A., Drimmie, R.J., Muir, D.C.G., Letcher, R.J., 2013. Three decades (1983-2010) of contaminant trends in East Greenland polar bears (Ursus maritimus). Part 2: brominated flame retardants. Environ. Int. 59, 494-500. https://doi.org/10.1016/j.envint.2012.09.008.

Dioses-Salinas, D.C., Pizarro-Ortega, C.I., De-la-Torre, G.E., 2020. A methodological approach of the current literature on microplastic contamination in terrestrial environments: current knowledge and baseline considerations. Sci. Total Environ. 730, 139164. https://doi.org/10.1016/j.scitotenv.2020.139164.

Dong, L., Zheng, L., Yang, S., Yan, Z., Jin, W., Yan, Y., 2017. Deriving freshwater safety thresholds for hexabromocyclododecane and comparison of toxicity of brominated flame retardants. Ecotoxicol. Environ. Saf. 139, 43-49. https://doi.org/10.1016/j. ecoenv.2017.01.005.

Drage, D., Mueller, J.F., Birch, G., Eaglesham, G., Hearn, L.K., Harrad, S., 2015. Historical trends of PBDEs and HBCDs in sediment cores from Sydney estuary, Australia. Sci. Total Environ. 512-513, 177-184. https://doi.org/10.1016/j.scitotenv.2015.01.034.

ECCC, 2016. Canadian Environmental Protection Act, 1999 Federal Environmental Quality Guidelines: Hexabromocyclododecane (HBCD). Available from. http://www ec.gc.ca/ese-ees/8BA57E1C-C4D7-4B37-A2CD-2EC50030C427/FEQG HBCD EN.pdf.

ECHA, 2019. Annex III inventory. Available from. https://echa.europa.eu/informationon-chemicals/annex-iii-inventory.

EU, 2011. Hexabromocyclododecane (HBCDD) EQS Dossier. European Union (EU), Brussels, Belgium Available from. https://circabc.europa.eu/sd/a/086ffe7c-8e634893-baac-994f3ff0eb34/HBCDD\%20EQS\%20dossier\%202011.pdf.

EU, 2013. Directive 2013/39/EU of the European Parliament and of the Council of 12 August 2013 amending Directives 2000/60/EC and 2008/105/EC as regards priority substances in the field of water policy. Available from. https://eur-lex.europa.eu/eli/ $\operatorname{dir} / 2013 / 39 /$ oj.

Feng, A.H., Chen, S.J., Chen, M.Y., He, M.J., Luo, X.J., Mai, B.X., 2012. Hexabromocyclododecane (HBCD) and tetrabromobisphenol A (TBBPA) in riverine and estuarine sediments of the Pearl River Delta in southern China, with emphasis on spatial variability in diastereoisomer- and enantiomer-specific distribution of HBCD. Mar. Pollut. Bull. 64, 919-925. https://doi.org/10.1016/j.marpolbul.2012.03.008.

Feng, M., Qu, R., Wang, C., Wang, L., Wang, Z., 2013. Comparative antioxidant status in freshwater fish Carassius auratus exposed to six current-use brominated flame retardants: a combined experimental and theoretical study. Aquat. Toxicol. 140-141, 314-323. https://doi.org/10.1016/j.aquatox.2013.07.001.

Frias, J.P.G.L., Nash, R., 2019. Microplastics: finding a consensus on the definition. Mar. Pollut. Bull. 138, 145-147. https://doi.org/10.1016/j.marpolbul.2018.11.022.

Gausepohl, H., Nießner, N., 2001. Polystyrene and styrene copolymers. In: Encyclopedia of Materials: Science and Technology. Elsevier, pp. 7735-7741. https://doi.org/10. 1016/B0-08-043152-6/01389-9.

Gu, S.Y., Ekpeghere, K.I., Kim, H.Y., Lee, I.S., Kim, D.H., Choo, G., Oh, J.E., 2017. Brominated flame retardants in marine environment focused on aquaculture area: occurrence, source and bioaccumulation. Sci. Total Environ. 601-602, 1182-1191. https://doi.org/10.1016/j.scitotenv.2017.05.209.

Hong, S.H., Rani, M., Jang, M., Han, G.M., 2013. Expanded polystyrene (EPS) buoy as a possible source of hexabromocyclododecanes (HBCDs) in the marine environment. Organohalogen Compd. 75, 882-885.

Hong, H., Li, D., Shen, R., Wang, X., Shi, D., 2014. Mechanisms of hexabromocyclododecanes induced developmental toxicity in marine medaka (Oryzias melastigma) embryos. Aquat. Toxicol. 152, 173-185. https://doi.org/10.1016/j. aquatox.2014.04.010.

Hong, S., Lee, J., Lee, C., Yoon, S.J., Jeon, S., Kwon, B.O., Lee, J.H., Giesy, J.P., Khim, J.S., 2016. Are styrene oligomers in coastal sediments of an industrial area aryl hydrocarbon-receptor agonists? Environ. Pollut. 213, 913-921. https://doi.org/10.1016/j. envpol.2016.03.025.

Jambeck, J.R., Geyer, R., Wilcox, C., Siegler, T.R., Perryman, M., Andrady, A., Narayan, R., Law, K.L., 2015. Plastic waste inputs from land into the ocean. Science 347, 768-771. https://doi.org/10.1126/science.1260352. (80-.).

Jang, M., Shim, W.J., Han, G.M., Rani, M., Song, Y.K., Hong, S.H., 2017. Widespread detection of a brominated flame retardant, hexabromocyclododecane, in expanded polystyrene marine debris and microplastics from South Korea and the Asia-Pacific coastal region. Environ. Pollut. 231, 785-794. https://doi.org/10.1016/j.envpol. 2017.08.066.

Kemmlein, S., Hahn, O., Jann, O., 2003. Emissions of organophosphate and brominated flame retardants from selected consumer products and building materials. Atmos. Environ. 37, 5485-5493. https://doi.org/10.1016/j.atmosenv.2003.09.025.

Klamer, H.J.C., Leonards, P.E.G., Lamoree, M.H., Villerius, L.A., Åkerman, J.E., Bakker, J.F., 2005. A chemical and toxicological profile of Dutch North Sea surface sediments. Chemosphere 58, 1579-1587. https://doi.org/10.1016/j.chemosphere.2004.11.027.
Kühn, S., Bravo Rebolledo, E.L., Van Franeker, J.A., 2015. Deleterious effects of litter on marine life. In: Marine Anthropogenic Litter. Springer International Publishing, pp. 75-116. https://doi.org/10.1007/978-3-319-16510-3_4.

Kuiper, R.V., Cantón, R.F., Leonards, P.E.G., Jenssen, B.M., Dubbeldam, M., Wester, P.W., van den Berg, M., Vos, J.G., Vethaak, A.D., 2007. Long-term exposure of European flounder (Platichthys flesus) to the flame-retardants tetrabromobisphenol A (TBBPA) and hexabromocyclododecane (HBCD). Ecotoxicol. Environ. Saf. 67, 349-360. https://doi.org/10.1016/j.ecoenv.2006.12.001.

Kwon, B.G., Moon, K. ran, 2019. Physicochemical properties of styrene oligomers in the environment. Sci. Total Environ. 683, 216-220. https://doi.org/10.1016/j.scitotenv. 2019.05.301.

Kwon, B.G., Saido, K., Koizumi, K., Sato, H., Ogawa, N., Chung, S.Y., Kusui, T., Kodera, Y., Kogure, K., 2014. Regional distribution of styrene analogues generated from polystyrene degradation along the coastlines of the North-East Pacific Ocean and Hawaii. Environ. Pollut. 188, 45-49. https://doi.org/10.1016/j.envpol.2014.01.019.

Kwon, B.G., Koizumi, K., Chung, S.Y., Kodera, Y., Kim, J.O., Saido, K., 2015. Global styrene oligomers monitoring as new chemical contamination from polystyrene plastic marine pollution. J. Hazard. Mater. 300, 359-367. https://doi.org/10.1016/j. jhazmat.2015.07.039.

Kwon, B.G., Amamiya, K., Sato, H., Chung, S.Y., Kodera, Y., Kim, S.K., Lee, E.J., Saido, K., 2017. Monitoring of styrene oligomers as indicators of polystyrene plastic pollution in the North-West Pacific Ocean. Chemosphere 180, 500-505. https://doi.org/10. 1016/j.chemosphere.2017.04.060.

Law, R.J., Covaci, A., Harrad, S., Herzke, D., Abdallah, M.A.E., Fernie, K., Toms, L.M.L., Takigami, H., 2014. Levels and trends of PBDEs and HBCDs in the global environment: status at the end of 2012. Environ. Int. https://doi.org/10.1016/j.envint.2014. 01.006.

Ma, H., Pu, S., Liu, S., Bai, Y., Mandal, S., Xing, B., 2020. Microplastics in aquatic environments: toxicity to trigger ecological consequences. Environ. Pollut. 261, 114089. https://doi.org/10.1016/j.envpol.2020.114089.

Mamaca, E., Bechmann, R.K., Torgrimsen, S., Aas, E., Bjørnstad, A., Baussant, T., Floch, S. Le, 2005. The neutral red lysosomal retention assay and comet assay on haemolymph cells from mussels (Mytilus edulis) and fish (Symphodus melops) exposed to styrene. Aquat. Toxicol. 75, 191-201. https://doi.org/10.1016/j.aquatox.2005.08.001.

Marvin, C.H., Tomy, G.T., Armitage, J.M., Arnot, J.A., McCarty, L., Covaci, A., Palace, V., 2011. Hexabromocyclododecane: current understanding of chemistry, environmental fate and toxicology and implications for global management. Environ. Sci. Technol. 45, 8613-8623. https://doi.org/10.1021/es201548c.

Morris, S., Allchin, C.R., Zegers, B.N., Haftka, J.J.H., Boon, J.P., Belpaire, C., Leonards, P.E.G., Van Leeuwen, S.P.J., De Boer, J., 2004. Distribution and fate of HBCD and TBBPA brominated flame retardants in North Sea estuaries and aquatic food webs. Environ. Sci. Technol. 38, 5497-5504. https://doi.org/10.1021/es049640i.

Mukai, Y., Goto, A., Tashiro, Y., Tanabe, S., Kunisue, T., 2020. Coastal biomonitoring survey on persistent organic pollutants using oysters (Saccostrea mordax) from Okinawa, Japan: geographical distribution and polystyrene foam as a potential source of hexabromocyclododecanes. Sci. Total Environ. 739, 140049. https://doi. org/10.1016/j.scitotenv.2020.140049.

OECD, 2007. SIDS Initial Assessment Profile for Cas. No. 25637-99-4, 3194-55-6, Hexabromocyclododecane (HBCDD). Available from. http://webnet.oecd.org/Hpv/ UI/handler.axd?id=ea58ac11-e090-4b24-b281-200ae351686c.

Oetken, M., Ludwichiwski, K.-U., Nagel, R., 2001. Validation of the Preliminary EUConcept of Assessing the Impact of Chemicals to Organisms in Sediment by Using Selected Substances. German Federal Environment Agency, Berlin (Report R+D project 2996-7411).

PlasticsEurope, 2019. Plastics-the facts 2019 an analysis of European plastics production, demand and waste data. Available from. http://www.plasticseurope.org/download file/view/3183/179.

Rani, M., Shim, W.J., Jang, M., Han, G.M., Hong, S.H., 2017. Releasing of hexabromocyclododecanes from expanded polystyrenes in seawater -field and laboratory experiments. Chemosphere 185, 798-805. https://doi.org/10.1016/j.chemosphere. 2017.07.042.

Reindl, A.R., Falkowska, L., 2020. Food source as a factor determining birds' exposure to hazardous organic pollutants and egg contamination. Mar. Freshw. Res. 71, 557. https://doi.org/10.1071/MF19159.

Rochman, C.M., Browne, M.A., Halpern, B.S., Hentschel, B.T., Hoh, E., Karapanagioti, H.K., Rios-Mendoza, L.M., Takada, H., Teh, S., Thompson, R.C., 2013. Policy: classify plastic waste as hazardous. Nature 494, 169-170. https://doi.org/10.1038/494169a.

Ruan, Y., Zhang, X., Qiu, J.W., Leung, K.M.Y., Lam, J.C.W., Lam, P.K.S., 2018. Stereoisomer-specific trophodynamics of the chiral brominated flame retardants HBCD and TBECH in a marine food web, with implications for human exposure. Environ. Sci. Technol. 52, 8183-8193. https://doi.org/10.1021/acs.est.8b02206.

Ruiz, P., Ortiz-Zarragoitia, M., Orbea, A., Theron, M., Le Floch, S., Cajaraville, M.P., 2012. Responses of conventional and molecular biomarkers in turbot Scophthalmus maximus exposed to heavy fuel oil no. 6 and styrene. Aquat. Toxicol. 116-117, 116-128. https://doi.org/10.1016/j.aquatox.2012.02.004.

Ryberg, M.W., Laurent, A., Hauschild, M., 2018. Mapping of Global Plastics Value Chain and Plastics Losses to the Environment. UNEP Available from. http://wedocs.unep. org/bitstream/handle/20.500.11822/26745/mapping_plastics.pdf.

Saido, K., Koizumi, K., Sato, H., Ogawa, N., Kwon, B.G., Chung, S.Y., Kusui, T., Nishimura, M., Kodera, Y., 2014. New analytical method for the determination of styrene oligomers formed from polystyrene decomposition and its application at the coastlines of the North-West Pacific Ocean. Sci. Total Environ. 473-474, 490-495. https://doi. org /10.1016/j.scitotenv.2013.12.081.

Shi, D., Lv, D., Liu, W., Shen, R., Li, D., Hong, H., 2017. Accumulation and developmental toxicity of hexabromocyclododecanes (HBCDs) on the marine copepod Tigriopus japonicus. Chemosphere 167, 155-162. https://doi.org/10.1016/j.chemosphere. 
2016.09.160

Smith, S.H., Taylor, L.T., 2002. Extraction of various additives from polystyrene and their subsequent analysis. Chromatographia 56, 165-169. https://doi.org/10.1007/ BF02493206.

Son, M.H., Kim, J., Shin, E.S., Seo, S. hee, Chang, Y.S., 2015. Diastereoisomer- and species-specific distribution of hexabromocyclododecane (HBCD) in fish and marine invertebrates. J. Hazard. Mater. 300, 114-120. https://doi.org/10.1016/j.jhazmat. 2015.06.023.

Tang, B., Zeng, Y.H., Luo, X.J., Zheng, X.B., Mai, B.X., 2015. Bioaccumulative characteristics of tetrabromobisphenol $\mathrm{A}$ and hexabromocyclododecanes in multi-tissues of prey and predator fish from an e-waste site, South China. Environ. Sci. Pollut. Res. 22, 12011-12017. https://doi.org/10.1007/s11356-015-4463-1.

Thomas, S., Kreuger, H.O., Kendall, T.Z., 2003. Hexabromocyclododecane (HBCD): A Prolonged Sediment Toxicity Test with Hyalella Azteca Using Spiked Sediment With $2 \%$ Total Organic Carbon. 439A-119B Wildlife International, Ltd. Project No, Easton (MD) (103 p).

Tian, Z., Kim, S.K., Hyun, J.H., 2020. Environmental distribution of styrene oligomers (SOs) coupled with their source characteristics: tracing the origin of SOs in the environment. J. Hazard. Mater. 398, 122968. https://doi.org/10.1016/j.jhazmat.2020. 122968.

Tongue, A.D.W., Reynolds, S.J., Fernie, K.J., Harrad, S., 2019. Flame retardant concentrations and profiles in wild birds associated with landfill: a critical review. Environ. Pollut 248, 646-658, https://doi.org/10.1016/j envpol.2019.01.103.

UNEP, 2013. SC-6/13: Listing of Hexabromocyclododecane.

UNEP, 2015. Drafted Guidance for the Inventory, Identification and Substitution of Hexabromocyclododecane (HBCD).

US EPA, 2018. Problem Formulation for Cyclic Aliphatic Bromides Cluster (HBCD).

Usenko, C., Abel, E., Hopkins, A., Martinez, G., Tijerina, J., Kudela, M., Norris, N., Joudeh, L., Bruce, E., 2016. Evaluation of common use brominated flame retardant (BFR) toxicity using a zebrafish embryo model. Toxics 4, 21. https://doi.org/10. 3390/toxics4030021.

Vorkamp, K., Bossi, R., Bester, K., Bollmann, U.E., Boutrup, S., 2014. New priority substances of the European Water Framework Directive: biocides, pesticides and brominated flame retardants in the aquatic environment of Denmark. Sci. Total Environ.
470-471, 459-468. https://doi.org/10.1016/j.scitotenv.2013.09.096.

Wathsala, R.H.G.R., Franzellitti, S., Scaglione, M., Fabbri, E., 2018. Styrene impairs normal embryo development in the Mediterranean mussel (Mytilus galloprovincialis). Aquat. Toxicol. 201, 58-65. https://doi.org/10.1016/j.aquatox.2018.05. 026.

Yoon, S.J., Hong, S., Kim, S., Lee, J., Kim, T., Kim, B., Kwon, B.O., Zhou, Y., Shi, B., Liu, P., Hu, W., Huang, B., Wang, T., Khim, J.S., 2020. Large-scale monitoring and ecological risk assessment of persistent toxic substances in riverine, estuarine, and coastal sediments of the Yellow and Bohai seas. Environ. Int. 137, 105517. https:// doi.org/10.1016/j.envint.2020.105517.

Zhang, Y., Ruan, Y., Sun, H., Zhao, L., Gan, Z., 2013. Hexabromocyclododecanes in surface sediments and a sediment core from Rivers and Harbor in the northern Chinese city of Tianjin. Chemosphere 90, 1610-1616. https://doi.org/10.1016/j. chemosphere.2012.08.037.

Zhang, H., Pan, L., Tao, Y., 2014a. Antioxidant responses in clam Venerupis philippinarum exposed to environmental pollutant hexabromocyclododecane. Environ. Sci. Pollut. Res. 21, 8206-8215. https://doi.org/10.1007/s11356-014-2801-3.

Zhang, Y., Sun, H., Zhu, H., Ruan, Y., Liu, F., Liu, X., 2014b. Accumulation of hexabromocyclododecane diastereomers and enantiomers in two microalgae, Spirulina subsalsa and Scenedesmus obliquus. Ecotoxicol. Environ. Saf. 104, 136-142. https:// doi.org/10.1016/j.ecoenv.2014.02.027.

Zhang, Y., Lu, Y., Wang, P., Li, Q., Zhang, M., Johnson, A.C., 2018. Transport of Hexabromocyclododecane (HBCD) into the soil, water and sediment from a large producer in China. Sci. Total Environ. 610-611, 94-100. https://doi.org/10.1016/j. scitotenv.2017.08.039.

Zhu, B., Lam, J.C.W., Yang, S., Lam, P.K.S., 2013. Conventional and emerging halogenated flame retardants (HFRs) in sediment of Yangtze River Delta (YRD) region, East China. Chemosphere 93, 555-560. https://doi.org/10.1016/j.chemosphere.2013.06. 052 .

Zuo, L., Sun, Y., Li, H., Hu, Y., Lin, L., Peng, J., Xu, X., 2020. Microplastics in mangrove sediments of the Pearl River Estuary, South China: correlation with halogenated flame retardants' levels. Sci. Total Environ. 725, 138344. https://doi.org/10.1016/j. scitotenv.2020.138344. 